\begin{tabular}{|l|l|l||}
\hline \multicolumn{2}{|c|}{ PublisherInfo } \\
\hline \hline PublisherName & $:$ & BioMed Central \\
\hline \hline PublisherLocation & $:$ & London \\
\hline \hline PublisherImprintName & $:$ & BioMed Central \\
\hline \hline
\end{tabular}

\title{
Testing times ahead
}

\begin{tabular}{|l|l|l||}
\hline \multicolumn{2}{|c|}{ ArticleInfo } \\
\hline \hline ArticleID & $:$ & 4592 \\
\hline \hline ArticleDOI & $:$ & $10.1186 /$ gb-spotlight-20020930-01 \\
\hline \hline ArticleCitationID & $:$ & spotlight-20020930-01 \\
\hline \hline ArticleSequenceNumber & $:$ & 258 \\
\hline \hline ArticleCategory & $:$ & Research news \\
\hline ArticleFirstPage & $:$ & 1 \\
\hline \hline ArticleLastPage & $:$ & 3 \\
\hline \hline & & RegistrationDate : 2002-9-30 \\
\hline ArticleHistory & $:$ & OnlineDate \\
\hline \hline ArticleCopyright & $:$ & BioMed Central Ltd2002-9-30 \\
\hline \hline ArticleGrants & $:$ & \\
\hline \hline ArticleContext & $:$ & 130593311 \\
\hline \hline
\end{tabular}


Friday October 4 is the deadline for replying to a consultation document from the UK's Human Genetics Commission (HGC): 'The supply of genetic tests direct to the public'. It comes amid renewed hope and hype about the future of genetic testing, with a raft of companies aiming to radically decrease the time and cost of providing individuals with genetic data.

Currently there is nothing to stop them selling these services directly to the public. American genetic entrepreneur Craig Venter claims clients are queuing up to pay $£ 400,000$ (US\$620,000) for having their genome transcribed to a $\mathrm{CD}$, while UK-based Solexa is aiming to give people a list of the points where critical genes vary from a pre-determined 'standard' for a fraction of that cost.

"Earlier this year the government asked the HGC to look into this and make recommendations to inform a Green Paper on genetics due out in 2003," HGC member Geoff Watts told The Scientist. "Previous voluntary guidelines cover supplying tests relating to medical conditions but it is increasingly obvious that as costs drop, companies will start offering tests for 'lifestyle' genetic testing."

An early example in the UK was the genetic testing company Sciona, which in spring 2002 started selling tests through high-street retailer The Body Shop, and was in talks with other outlets. "After comments in the Press, and a few letters from genetics professionals to the companies involved, all of the big companies pulled out," says Martin Bobrow, professor of medical genetics at the Cambridge Institute for Medical Research.

But Bobrow believes this example of sense within the marketplace should not breed complacency. "There is a substantial marketing opportunity here. Science in general and genetics in particular has a public appeal, which can be used very aggressively and very misleadingly," he says, pointing to the pseudo-scientific statements attached to many healthfood and cosmetics products.

Bobrow believes that so-called 'lifestyle' testing has an innocuous affect on people's life and could be left to the market, but tests for serious genetic disorders should be regulated. He would like to see a specific requirement that people who make scientific claims for their products have recognizable scientific evidence. "Then we can allow the public to make adult decisions."

"At the same time as treating people as adults, we need to protect children," says genetic counsellor Caroline Berry. "While children obviously may need tests to diagnose conditions like retinoblastoma, which will affect them while they are young, they do not belong to their parents and should not be given tests simply at the request of their parents. Children are people in their own right and parentally driven testing precludes their making an informed decision for themselves when they are older."

Although all serious commentators agree that the technology for selling genetic tests to the public is not currently available, they also believe that ground rules need setting now. Meanwhile, a special session at next week's Genome Sequencing and Analysis conference in Boston will look at the practicalities of making the $\$ 1000$ genome a reality. 


\section{References}

1. Human Genetics Commission, [http://www.hgc.gov.uk]

2. The supply of genetic tests direct to the public, [http://www.hgc.gov.uk/testingconsultation/ index.htm]

3. Solexa, [http://www.solexa.co.uk]

4. Sciona, [http://www.sciona.com]

5. Martin Bobrow, [http://www.cimr.cam.ac.uk/people/profiles/bobrow_martin_profile.html]

6. Cambridge Institute for Medical Research, [http://www.cimr.cam.ac.uk/]

7. 14th International Genome Sequencing and Analysis Conference, [http://www.tigr.org/conf/gsac/ agenda.shtml] 